\title{
„DLA MNIE ŻYĆ - TO CHRYSTUS!" (FLP 1, 21) - PAWLOWA ODPOWIEDŹ NA ODWIECZNE PYTANIE O SENS LUDZKIEGO ŻYCIA
}

Epoka, w której żyjemy, charakteryzuje się wielkim przyśpieszeniem przemian, jakie dokonują się $\mathrm{w}$ różnych dziedzinach życia społecznego. Wiele wartości uważanych za stałe, niezmienne, podważa się i kwestionuje. Wiele osób młodych i starszych nie może się odnaleźć w tym świecie, gdzie obok wspaniałych odkryć, wielkiego postępu, jest także bardzo dużo wypadków lekceważenia człowieka, deptania jego najbardziej podstawowych praw. Obserwujemy ucieczkę od rzeczywistości, odwracanie się od świata, w którym nie widzi się dla siebie możliwości pożytecznego działania. Pytanie o sens ludzkiego życia stawia się ze szczególną siłą.

Jako chrześcijanie możemy i powinniśmy szukać odpowiedzi na to pytanie w Bożym Objawieniu. Pismo Święte jednoznacznie mówi nam o wartości ludzkiego życia jako wielkiego daru Boga, który $\mathrm{w}$ obecnej formie jest jednocześnie zadaniem; etapem przygotowawczym, od którego zależy nigdy nie kończące się bytowanie w wieczności. Najważniejsze są dla nas teksty Nowego Testamentu, które bardzo mocno wiążą nasze życie z Chrystusem. Syn Boży bowiem dla nas stał się człowiekiem, przyjął nasz sposób życia, aby doprowadzić nas do swojego boskiego życia. Kto rozumie choć cząstkę z niezgłębionych bogactw Bożej miłości objawionej przez Jezusa Chrystusa, ten zna doskonale odpowiedź na pytanie o sens ludzkiej egzystencji. Rozważymy kilka tekstów, łączących nasze życie $\mathrm{z}$ Jezusem Chrystusem, wychodząc od przytoczonego $w$ tytule wiersza z Listu św. Pawła do Filipian, by przez to zestawienie zobaczyć, jak Słowo Boże wychodzi naprzeciw ludzkim oczekiwaniom i rozjaśnia mroki ludzkiej niewiedzy i wątpliwości.

Św. Pawel pisze $\mathrm{z}$ więzienia list do swojej umilowanej gminy, pierwszego z kościołów, jakie Apostoł Narodów założył w Europie (por. $\mathrm{Dz} 16,12$ ), związanego z nim szczególnym węzłem serdeczności. Chyba żaden inny spośród Listów św. Pawła nie zawiera tylu osobistych wynurzeń ${ }^{1}$. Po pozdrowieniu Autor opisuje swoją aktualną sytuację, działalność apostolską w więzieniu oraz działalność innych, niekiedy spowodowaną zawiścią wobec Wielkiego Apostoła ${ }^{2}$. Więzień cieszy się $z$ tego, że nauka Ewangelii staje się coraz bardziej znana w środowiskach pogańskich i wyraża gotowość przyjęcia wszystkiego, co Bóg dla niego zamierzy, ponieważ posłuży to do uwielbienia Chryistusa. „Lecz jak zawsze, tak i teraz, $z$ całą swobodą i jawnością

1 Por. np. 1, 21-24; 2, $17 \mathrm{n} ; 3,7-14 ; 4,11-13$.

2 1, 14. 17. Por. A. Ja n kow ski, Listy więzienne, Poznań 1962, s. 89. 91 . 
Chrystus będzie uwielbiony w moim ciele: czy to przez życie, czy przez śmierć" (w. 20). Ponieważ Apostoł należy calkowicie do Chrystusa, jest gotów zarówno ponieść męczeństwo jak też kontynuować działanie apostolskie ${ }^{8}$. Jego ciało jest narzędziem Bożej sprawy, podobnie jak Chrystus w swoim ciele stał się narzędziem przebłagania (Rz 3, 25). Męczeństwo stanowi zakończenie życia oddanego Chrystusowi, jakby pieczęć kończącą dotychczasowe czyny zapisane w księdze życia, o której mówi Apostoł w tym samym liście ${ }^{4}$. Tam wprawdzie do księgi wpisuje się przede wszystkim imiona wybranych, niemniej tradycja judaistyczna, której Paweł był wytrawnym znawca, znała także księgi obejmujące ludżkie czyny - złe lub dobre, rodzaj kroniki całej ludzkości i poszczególnych osób ${ }^{5}$. Paweł pragnie takiego potwierdzenia tego, czego dotąd dokonał, a przede wszystkim pragnie „być z Chrystusem" (1,23). Jest także gotów kontynuować dotychczasową pracę, ponieważ taka jest jego rola w Bożych planach. Oceniając sytuację przewiduje, że jeszcze nie nadeszła pora męczeństwa i pisze: „A ufny $w$ to, wiem, że pozostanę, i to pozostanę nadal dla was wszystkich, dla waszego postępu i radości w wierze" (w. 25).

Obydwie możliwości mają swoje dobre strony: „być z Chrystusem..., to o wiele lepsze, pozostawać zaś w ciele - to bardziej dla was konieczne" (w. $23 \mathrm{n}$ ). Największą wartością jest zjednoczenie z Chrystusem, „o wiele lepsze" od czegokolwiek innego. Można powiedzieć, że obie możliwości odpowiadają dwu największym przykazaniom miłości Boga i bliźniego; śmierć dla Chrystusa to zakończenie stanu rozłączenia, ostateczne zjednoczenie z Nim, pełnia miłości, której już nic nie przeszkodzi. Natomiast pozostawanie w ciele to dostosowanie się do potrzeb braci, dla których obecność Pawła i jego praca ma bardzo duże znaczenie. Ponieważ tak jest, trzeba na razie zrezygnować z tego, co „o wiele lepsze" dla Pawła, aby spełniło się to, ,,co bardziej konieczne" dla jego uczniów.

Takie spojrzenie na własną śmierć i własne życie możliwe jest dla kogoś, kto całkowicie oddał się Chrystusowi. Zakończenie ziemskiego życia to nie koniec naszej egzystencji, ale ,bycie z Chrystusem", osiągnięcie celu tej egzystencji. Interesującym zagadnieniem jest wyrażone $\mathrm{w}$ niektórych miejscach $u$ św. Pawła ogólnoludzkie pragnienie, by zjednoczyć się z Chrystusem bez utraty życia w ciele ${ }^{6}$, jednakże sam sposób zjednoczenia z Chrystusem, czy od razu jako pełny

3 Dz. cyt., s. 95.

4 4, 3. Księga życia - symbol wybrania do łaski, występuje także w Wj $32,32 \mathrm{n}$; Ps $69(68), 25$ i Ap 3,$5 ; 13,8 ; 20.12 .15 ; 21,27$. Jest to wywodzący się ze Starego Testamentu oraz literatury judaistycznej obraz aktualny także w imperium rzymskim, które prowadziło dokładne listy obywateli dla celów podatkowych. Por. A. J ankowski, dz. cyt., s. 168.

5 Por. H. Strack, P. Billerbeck, Kommentar zum Neuen Testament aus Talmud und Midrasch, München 1954, II, S. 169-176; zwlaszcza s. 170-174. Biblijne analogie por. Ezd 4, 15; Est 2, 23; 6, 1; 10, 2; Iz 65, 6; Dn 3, 12; Ml 3, 16; Łk 10, 10; Ap 20, 12. 3.

${ }_{6}$ Por. 1 Kor 15, 52; 2 Kor 5, 4; 1 Tes 6, 16. 
człowiek - z duszą i ciałem, czy też na razie tylko dusza, podczas gdy ciało połączy się z nią dopiero po powszechnym zmartwychwstaniu $^{7}$ - jest rzecza drugorzędną w stosunku do najwyższej wartości bycia z Chrystusem. Czy przez śmierć, czy też przez dalsze życie, można, choć na różne sposoby, być z Nim. Paradoksalnym może się wydać zestawienie, być z Chrystusem", jako stanu po śmierci, z użytym w tytule niniejszego artykułu zwrotem: „dla mnie żyć to Chrystus". Wydaje się, że skoro z Chrystusem można być dopiero po śmierci, to życie w ciele jest oddaleniem od Niego (por. 2 Kor 5, 6), niemniej św. Paweł łączy to w jedno. Dzieje się tak na zasadzie, tzw. "continuum eschatologicznego" (C. K. Barrett), gdyż związek z Chrystusem się zaczął, ale nie dopełnił ostatecznie.

„Dla mnie żyć - to Chrystus". Lapidarne sformułownaie Apostoła Narodów dopuszcza różne możliwości interpretacji. Najbardziej prawdopodobne wydaje się rozumienie imienia "Chrystus" jako głoszenie Chrystusa, czyli budowanie Jego eklezjalnego Ciała, realizację w Kościele „miary dojrzałości odpowiedniej do Pełni Chrystusa” (Ef 4, 13) ${ }^{8}$. Chrystus chwalebny w niebie istnieje także na ziemi jako nadprzyrodzony organizm, którego jest Głową, i który tu i teraz stanowi dany nam sposób zjednoczenia się z Bogiem. Chociaż śmierć uważa św. Paweł za zysk (w. 21 b), to jednak wie, że na razie ona nie nastąpi, że czeka go jeszcze praca, która będzie wypełnieniem przykazania miłości, głoszeniem Tego, który sam jest Miłością i prowadzeniem braci do zjednoczenia $\mathrm{z}$ Nim.

Chrystus stanowi zasadę życia Apostoła i jego wiernych ${ }^{9}$. Najmocniej chyba wyraża tę prawdę św. Paweł w innym z Listów więziennych, skierowanych do Kolosan: "Gdy się ukaże Chrystus, nasze życie, wtedy i wy razem z Nim ukażecie się w chwale" (3, 4). Inny kontekst, związany $\mathrm{z}$ wiarą $\mathrm{w}$ zmartwychwstanie, którego rękojmia jest zmartwychwstanie Chrystusa, a która zobowiązuje do umartwienia, poddania się całkowicie Chrystusowi i odrzucenia wszystkiego, co się Mu sprzeciwia i która wyraża się we wzajemnej miłości w rodzinach i we wszystkich dziedzinach życia, kiedy kontaktujemy się z różnymi kategoriami bliźnich. Patetyczny zwrot św. Pawła ${ }^{10}$ podkreśla związek naszego życia z Chrystusem zmartwychwstałym, związek stanu, w jaki zostaliśmy wszczepieni przez chrzest, stanowiący śmierć dla tego, co dawne i grzeszne (por. Ef 3, 3; 2, 20; Rz 6, 3-7) z Jego mocą życiodajną. Jest to związek tak silny, że słusznie można identyfikować nasze obecne życie z Chrystusem.

Możemy zestawic sformulowania $z$ listów św. Pawła ze znamiennym samookreśleniem, jakie św. Jan w swojej Ewangelii włożył

7 Por. T. Dąbek, Biblijna rzeczywistość ciała po zmartwychwstaniu, „Analecta Cracoviensia” 16 (1984), s. 395-407, 403.

8 A. J ank ow ski, Listy więzienne, dz. cyt., s. 96.

9 Tamże. Por. Rz 8, 10; Ga 2, 20; Kol 3, 4.

10 Por. A. J a nkowski, Listy więzienne, dz. cyt., s. 280. 
w usta Jezusa: „Ja jestem drogą i prawdą i życiem” (J 14, 6). Tekst stanowiący fragment mowy $\mathrm{W}$ Wieczerniku przed Męką wchodzi w skład wypowiedzi o drodze do Ojca, do którego Jezus odchodzi i o poznaniu Ojca przez Syna. Stwierdzenie, że On jest życiem, odpowiada treści mowy eucharystycznej z szóstego rozdziału Ewangelii: chleb życia, którym jest ciało Jezusa (w. 32-58) to kontynuacja Jego życiodajnej działalności, głoszenia nauki, która również jest duchem i życiem ( $\mathrm{J} 6,63)$. Życie wiąże się ściśle $\mathrm{z}$ prawdą ważnym tematem teologicznym Czwartej Ewangelii ${ }^{11}$, a $z$ kolei życie św. Pawła w ciele to także głoszenie prawdy - Chrystusa jako prawdy, wszystkim narodom. Chrystus przyniósł na świat Bożą prawdę od Ojca, początku i źródła wszelkiego istnienia i ta prawda prowadzi do życia - pozwala się radować darem Ojca ${ }^{12}$. Boże życie, udzielone na początku stworzenia, nie mogło osiągnąć swojej pełni przez grzech, po którym przyszła na świat śmierć ${ }^{\mathbf{1 8}}$. Teraz Chrystus przywraca stan początkowy, On, który jest Słowem Wcielonym: w Nim było życie, które jest światłością ludzi ${ }^{14}$. Przez Niego mamy przystęp do Ojca (Ef 2,18), od którego odeszliśmy.

Mocne sformułowania, identyfikujące życie i Jezusa Chrystusa, opierają się na bardzo wielu tekstach Starego i Nowego Testamentu, które, mówiąc o związku życia z Bogiem, przygotowują tę identyfikację. Opisy stworzenia świata i człowieka przedstawiają bardzo wyraźnie pochodzenie życia od Boga. Wszystko powstało z Jego woli, a w całym tym stworzonym świecie szczególne miejsca zajmuje człowiek stworzony na Jego obraz i podobieństwo (Rdz 1, $26 \mathrm{n})$, obdarzonego „tchnieniem życia" (hebr. niš̌mat hajjîm - Rdz 2, 7), które nabiera szczególnego znaczenia, gdy uświadomimy sobie, że życie jest nie tylko wspólną cechą człowieka i przyrody ożywionej, w szczególności zaś zwierząt, lecz że również sam Bóg bardzo często jest nazywany Bogiem żywym ${ }^{15}$. Ta cecha służy nie tylko do odróżnienia i przeciwstawienia Go bożkom pogańskim, ale przede wszystkim podkreśla, że jest On źródłem wszelkiego bytowania, tylko On posiada absolutną pełnią życia, a wszystko inne tylko uczestniczy w, Jego życiu. Przysięga „na życie Jahwe" stanowiła najbardziej wiarygodne potwierdzenie czyichś słów w Starym Testamencie, do tego stopnia, że $\mathrm{w} \mathrm{Lb} \mathrm{14,} 21$ sam Jahwe przysięga na własne życie ${ }^{16}$.

Ludzie Starego Testamentu bardzo cenili życie doczesne - długie i szczęśliwe - jako nagrodę za sprawiedliwe postępowanie w obliczu

11 Por. R. E. Brown, The Gospel according to John, XIII-XXI, Garden City-New York 1970, s. 631.

12 Por. H. van den Bussche, Jean, (Bruges) 1967, s. 399.

13 Por. Rz 5, 12.

$14 \mathrm{~J} \mathrm{1}, 4$. Por. C. K. B arrett, The Gospel according to St. John, London 1967, s. 382.

15 Por. Joz 3, 10; Ps 42 (41), 3.

16 Por. Sdz 8, 19; 1 Sm 19, 6; ,wyrocznia Jahwe” w zapowiedziach prorockich - np. Jr 22, 24; 23, 7 n; Ez 5, 11. 
Boga ${ }^{17}$. Nauka o zmartwychwstaniu stopniowo ukazuje się $\mathrm{w}$ kolejnych księgach - doczesne życie to nie tylko wartość ziemska, bytowanie podobne do sposobu istnienia zwierząt, ale także istnienie na chwałę żyjącego Boga, który obdarzył życiem swoje stworzenia ${ }^{18}$.

Stopniowo członkowie Ludu Wybranego coraz lepiej dostrzegają, $\dot{z}$ e to doczesne życie jest kruche, nietrwałe ${ }^{19}$. Podsumowanie dotychczasowej nauki Bożego Objawienia o tym, czym jest rzeczywiście ludzkie życie, przynosi Księga Mądrości, głosząc, iż to doczesne życie przemija $(2,2 \mathrm{n})$, natomiast za postępowanie w czasie, który Bóg dał nam tutaj spędzić, czeka nas nagroda, albo kara; męka nie dosięgnie dusz sprawiedliwych, choćby pozostawali $w$ mocy swych wrogów, natomiast bezbożni poniosą karę według swych zamysłów ${ }^{20}$.

Prawdziwe życie Izraelity to nie tyle życie doczesne, ile trwanie $\mathrm{w}$ jedności z Bogiem, wypełnianie Jego przykazan, które są jednocześnie warunkami przymierza, jakie zawarł On ze swoim ludem i szukanie Go w swoim życiu. Wyraźnie mówią o tym prorocy ${ }^{\mathbf{2 1}}$. W Psalmie 63 (62) znajdujemy jeszcze mocniejsze sformułowanie: „モaska Twoja lepsza jest od życia” (w. 4) - dzięki łasce życia odnajduje swój właściwy sens ${ }^{22}$, ponieważ ostatecznie wartość wszystkiego płynie $\mathrm{z}$ jego związku z Bogiem, jedności z łaską, która jest dobrem najwyższym.

Tę prawdę najpełniej ukazał w swoim nauczaniu Jezus Chrystus, przypominając w Kazaniu na górze, iż Bóg troszczy się o całe stworzenie - o ptaki latające w powietrzu, a tym bardziej o człowieka stworzonego na Jego obraz i podobieństwo ${ }^{28}$. Chcąc osiągnąć życie należy się troszczyć nie o dobra przemijające, lecz o zachowanie Bożych przykazań ${ }^{24}$ i być gotowym ofiarować wszystko dla najwyższej wartości Dobrej Nowiny przyniesionej przez Jezusa ${ }^{25}$, która się utożsamia $\mathrm{z}$ życiem wiecznym. Natomiast grzech - przeciwieństwo dobrego postępowania, prowadzi do śmierci wiecznej: wieczny ogień przygotowany jest diabłu i jego aniołom oraz tym wszystkim, którzy nie pełnili uczynków miłości bliźniego ${ }^{26}$.

Spośród ewangelijnych przekazów szczególnie bogata w przenośnie i obrazy odnoszące się do życia jest Ewangelia św. Jana, z której

17 Por. $\mathrm{Rdz} 25,7-8$; Hi 42, 16-17.

18 Por. n.p. Psalm $104(103)$ - radosny hymn pochwalny na cześć Boga, którego wielkość przejawia się w rozmaitości stworzeń. Tę samą myśl wyrażają téz ostatnie rozdziały Księgi Hioba.

19 Por. Hi 14, 1-2; Ps $37(36) ; 39(38), 6-7 ; 144(143), 4$.

20 Por. Mdr 3, 1-10.

21 Am 5, 4: „Szukajcie Mnie, a żyć będziecie”, por. Oz 6, 1-3; Prz 14, 27; Ps $36(35), 10$.

${ }_{22}$ Por. H. Gross, H. Reinelt, Das Buch der Psalmen, I, Leipzig 1978 , s. 337.

${ }_{23}$ Mt 6, 25-34; Łk 12, 22-31.

24 Mt 19, 17.

25 Por. Mk 8, 35 par.; 9, 43 par.; 10, 30 par.

26 Por. Mt 25, 41-46. 
kilka tekstów już omówiliśmy. Chrystus Pan, „droga, prawda i życie” ( $J$ 14, 6) określa siebie również jako ,zmartwychwstanie i życie" $(11,25)$. On głosi słowo życia $(J$ 6, 63. 69), przykazania życia pochodzące od Ojca $(12,50)$. Życie jest światłością ludzi $(1,4)$ - tą samą światłością nazywa siebie także sam Jezus $(8,12)$. On zaprasza uczniów, by czerpali od Niego wody życia (4, 10. 14; 7, 17-19); Ewangelista wyjaśnia, że ,powiedzial to o Duchu, którego mieli otrzymać wierzący w Niego" (7, :9). Wielorakie powiązania między Chrystusem i Jego dziełem a Duchem Swiętym trwają nadal w odniesieniu do Kościoła - Ciała Chrystusowego i jego członków. Chrystus, który sam jest życiem, udziela swego życia przez Ducha Świętego i przez chleb życia - swoje eucharystyczne Ciało ${ }^{27}$.

Alegoria o Dobrym Pasterzu zawiera dwie bardzo ważne myśli charakteryzujące działanie Jezusa. On przyszedł po to, aby owce miały życie i miały je w obfitości ( $\mathrm{J} 10,10)$. Dokonuje tego oddając swoje życie za owce calkowicie dobrowolnie, na mocy nakazu, jaki otrzymał od Ojca i ta ofiara powoduje, że najpierw On sam odzyska życie $(\mathrm{J} 10,11.15 .17 \mathrm{n})$ a potem udzieli go swoim owcom. Dlatego pierwotny Kościół sławi Go jako Daweę życia (Dz 3, 15), dosłownie jako Tego, który je zapoczątkował i dalej rozwija.

Pełne ekspresji sformułowanie św. Pawła z Listu do Filipian wyraża zatem jedno $z$ podstawowych twierdzeń religii objawionej: życie ludzkie pochodzi od Boga, który człowieka stworzył i powołał do uczestnictwa w swoim nadprzyrodzonym sposobie bytowania, przez swojego jednorodzonego Syna ogłosił pełnię prawdy, dającej życie wieczne, a przez ofiarę Jego życia usunąl to, co uniemożliwiało ludziom udział w boskim życiu. Dlatego nowe życie ochrzczonych znajduje swój najpełniejszy sens w Chrystusie, Dawcy i Zasadzie życia, któremu należy się od nas wszystko i praca dla Niego jest najdoskonalszym sposobem wykorzystania tych dni, które On nam daje na tej ziemi.

Inny fragment $z$ pism św. Pawła przypomina, że nie jesteśmy absolutnymi właścicielami naszego życia: „Nikt zaś z nas nie żyje dla siebie i nikt nie umiera dla siebie: jeżeli bowiem żyjemy, żyjemy dla Pana, jeżeli zaś umieramy, umieramy dla Pana. I w życiu więc i w śmierci należymy do Pana. Po to bowiem Chrystus umarł i powrócił do życia, by zapanować tak nad umarłymi, jak nad żywymi" (Rz 14, 7-9). Jeżeli będziemy zawsze o tym pamiętali i przypominali tę prawdę naszym braciom, nie będą do nas miały przystępu wątpliwości co do sensu naszego istnienia.

\section{Tyniec}

O. TOMASZ MARIA DABEK OSB

27 Por. J 6, 16--71. Omówienie nauki Ewangelii św. Jana o życiu zawiera praca Ks. J. Czerski e go, Pojęcie życia w przenośniach czwartej Ewangelii, w: Egzegeza Ewangelii św. Jana, pr. zb. pod red. F. Gryglewicza, Lublin 1976, s. 169-181. 